\title{
EFFICIENCY OF USING ELECTRONIC DICTIONARIES IN THE PROCESS OF LECTURING FOREIGN LANGUAGES AT INSTITUTIONS OF HIGHER EDUCATION
}

\section{ЕФЕКТИВНІСТЬ ВИКОРИСТАННЯ ЕЛЕКТРОННИХ СЛОВНИКІВ У ПРОЦЕСІ ВИКЛАДАННЯ ІНОЗЕМНИХ МОВ У ЗАКЛАДАХ ВИЩОЇ ОСВІТИ}

\begin{abstract}
In the article, the problematic issues of increasing the efficiency of using the information and communication technologies (ICT) (in particular, electronic dictionaries) in the process of lecturing foreign languages at institutions of higher education (IHE) are considered. It is determined that using different means of the ICTS (in particular, electronic dictionaries) give the opportunity to create the individual educational approach. The role of electronic dictionaries (e-dictionaries) in organizing the educational process is identified, the ways of using e-dictionaries are described. It is proved that using this technology contributes to developing various types of students' work and creating conditions for effectively organized work when studying foreign languages. Using e-dictionaries while lecturing foreign languages shows that they are not only a source of qualitative reference material but also a useful and indispensable modern means of teaching and learning foreign languages. It is also determined that there is an urgent and relevant need to substantiate theoretically and to develop new teaching methods of foreign languages using e-dictionaries adequately and correctly for practical implementation at the lessons of foreign languages and when performing different types of students' work. The paper presents the author's try to consider the advantages and disadvantages of using e-dictionaries in the learning and teaching process; to analyze the opportunities created by using e-dictionaries as to differentiate the educational and upbringing process, to develop as much as possible students natural skills, abilities, needs, demands, to uncover students' creative potential; to consider the impact of using e-dictionaries on forming necessary life competences and scientific-technological culture of future professionals of higher education, that is nowadays they are the inseparable component of common culture of every man and society in general.

Key words: information and communication technologies, electronic dictionaries (e-dictionaries), institutions of higher education, means of modern teaching and learning, creative personality.
\end{abstract}

Устаттірозглядаютьсяпроблемніпитання підвищення ефрективності використання інсрормаційно-комунікаційних технологій (IKT) (зокрема, електронних словників) у прочесі викладання іноземних мов у закладах вищої освіти (ЗВО). Визначено, що використання різних засобів IKT (зокрема, електронних словників) дає можливість створювати індивідуальний підхід до навчання. Визначено роль електронних словників в організації навчального прочесу, описано шляхи використання електронних словників. Доведено, що використання цієі технології сприяє розвитку різних видів роботи студентів та створенню умов для есрективної організації роботи під час вивчення іноземних мов. Використання електронних словників під час викладання іноземних мов показує, що вони є не тільки джерелом якісного довідкового матеріалу, але й корисним i незамінним сучасним засобом навчання та викладання іноземних мов. Також визначено, що $\epsilon$ нагальна та актуальна потреба теоретично обґрунтувати та розробити нові методи навчання іноземних мов із використанням електронних словників належно та адекватно для практичної реалізаціі різноманітних видів діяльності на уроках іноземних мов та для виконання різних видів студентської роботи. У статmі представлено авторську спробу розглянути переваги та недоліки використання електронних словників у прочесі навчання; проаналізувати можливості, створені за допомогою електронних словників, щоб диференціювати освітній $і$ виховний процес, розвивати якомога більше природних навичок, здібностей, потреб, вимог, розкривати творчий потенціал студентів; розглянути вплив використання електронних словників на формування необхідних життєвих компетенцій науковотехнічної культури майбутніх фоахівців вищої освіти, бо нині вони є невід'ємним складником загальної культури кожної людини і суспільства в цілому.

Ключові слова: інформаційно-комунікаційні технології, електронні словники, заклади вищої освіти, засоби сучасного викладання й навчання, творча особистість.
The problem statement in general. Lecturers' work with students whether it is classroom or individual, educational or upbringing is the most important component of the educational process at institutions of higher education (the IHE). Its aim is to form a creative personality who is able to perform self-development, self-education, innovative activities not only while studying at the IHE but during the whole life: a modern human being should, and even must learn to accept and to analyze the huge amount of new information, expressing critical attitude to its assessment, being able to use information properly. In connection with the process of globalization learning foreign languages (especially, English) is of an urgent necessity nowadays. Pedagogues, innovators, scholar, lecturers of higher school under the new conditions offer new teaching methods and techniques, in particular using the information and communication technologies (the ICT) when teaching foreign languages. Today, the basic goal of teaching a foreign language to students of all specialities is to master it in practice, i. e. communicative abilities and skills, which is an integral component of the education of an intelligent person. To provide favourable conditions for mastering a foreign 
language at a lesson, it is necessary to create a real communicative situation so that the language learnt acts as a means of communication. L. Cherniakova rightly points out that when studying a foreign language by students of all specialities it is very important to master not only its theory (grammar rules) but what is more important, the practice of communication. The author believes that each lecturer should independently select such exercises and tasks that while doing them students will develop not only speech but also their creative activity [3]. Using the ICT when teaching and learning foreign languages provides an imitation of a foreign language environment, creates conditions for authentic communication, allows for taking into account the individual characteristics of students, gives the opportunity to increase motivation to learn a foreign language and intensify the development of skills specific to this or that language discipline. The interactive computer teaching of a foreign language is one of the essential direction of teaching and learning a foreign language.

The development and practical application of information and communication technologies in the educational process takes a relatively short period of time. But this problem is becoming more and more relevant to the course of the political development of Ukraine and its integration into the global space. First of all, it concerns the English language as this language is the window into the world of innovations, technologies, and business.

Analysis of the recent investigations and scientific publications. The process of informatization of society and education has been studied and reflected in the domestic and foreign pedagogical literature. In particular, using the ICT in the educational and upbringing process is considered by V. Bespalko, V. Bykov, M. Bukharkina, T. Holubieva, R. Hurevych, O. Karelina, V. Krasnopolskyi, Ye. Polat, S. Repina, O. Romanyshyna, R. Schenck, L.R. Yang, and some others. Using the ICT in the process of teaching and learning foreign languages is investigated by V. Krasnopolskyi, L. Morska, Ye. Polat, E. Robert, D. Taushan, etc. The historical approach of spreading different types of computer technologies in the educational process is presented in the works by O. Ahapova, A. Kryvosheiev, A. Ushakov. S. Huchetl, Ya. Hryshchenko, Z. Devterova investigate the peculiarities of implementation of the ICT in the process of students' individual work. P. Sysoiev, $M$. Yevstyhnieiev are engaged in creating the authors' Internet-resources in foreign languages. The problem mentioned is urgent for pedagogues-practitioners as it is widely discussed at pedagogical meetings, foreign language trainings, workshops, virtual communities, on the pages of the pedagogical press. But it is necessary to note that the issues of conducting lessons of foreign languages with using the ICT, in our case electronic dictionaries or e-dictionaries, is not sufficiently developed in the pedagogicalscientific literature. Taking into account everything mentioned above there is an urgent and relevant need to substantiate theoretically and to develop new teaching methods of foreign languages using e-dictionaries adequately and correctly for practical implementation at the lessons of foreign languages and when performing students' individual work.

Formulating the purpose of the paper. The purpose of the paper is to analyze peculiarities of using e-dictionaries at the lessons of foreign languages while teaching and learning them, and when performing students' individual work in the process of learning foreign languages.

The purpose needs solving the following objectives: 1) to consider the advantages and disadvantages of using e-dictionaries in the learning and teaching process; 2) to analyze the opportunities created by using e-dictionaries as to differentiate the educational and upbringing process, to develop as much as possible students' natural skills, abilities, needs, demands, to uncover students' creative potential; 3 ) to consider the impact of using e-dictionaries on forming necessary life competences and scientific-technological culture of future professionals of higher education, that is nowadays is the inseparable component of common culture of every man and society in general.

Presentation of the main research material. Analyzing the problem of using e-dictionaries while learning foreign languages one can distinguish such positive moments of their being implemented into the process as: motivating the learning process even more than audio and video materials; giving the opportunity to use the individual approach; contributing to the development of students' independence, stimulating to use information that is relevant to students' personal or professional lives; increasing students' awareness of other languages and cultures; increasing the language competences due to different types of e-dictionaries; providing the modern material that meets students' interests and needs; offering the authentic and relevant material.

Nowadays there are many computer and online programs for learning, developing and mastering students' knowledge of foreign languages, their language and speech abilities, and skills. All these programs can be divided into the four basic categories:

1. Electronic dictionaries or e-dictionaries (Abbyy Lingvo, Webster's Dictionary, Longman Dictionary, Macmillan English Dictionary, Collins English Dictionary and many others), that give opportunity to find quickly any word with all its meanings and possible grammar forms, listen to the sounded pronunciation and view the examples of sentences with the given word to understand its meanings in different contexts.

2. Electronic translators that allow translating big texts (Prompt, Magic Goody, Google Translator, 
M-Translate and others), which do not always present the adequate and correct translations that correspond to all the syntactic, stylistic and grammar norms of the given foreign language.

3. Different programs for learning foreign languages, oriented to their audience and the level of the language mastering. They can be used at different stages of work with the lexical and grammar material.

4. Different programs for testing the knowledge of foreign languages (online testing TOEFL, IELTS, and others) serve for checking and controlling the knowledge, defining the general level of mastering the foreign language.

Besides the above-mentioned categories, it is necessary to point out the existence of special programs for teachers and lecturers, which allow performing the electronic testing of their students. These programs have become indispensable in the process of checking and grading students' works, as they significantly save lecturers' time.

In the paper presented the basic attention is paid to using e-dictionaries as they are modern, relevant and mobile means of optimizing the process of translating foreign vocabulary. Unfortunately, most students do not know how to work with dictionaries properly, and moreover with the electronic ones. But such means of learning foreign languages can be rather effective.

First of all, let us analyze using e-dictionaries in the educational and upbringing process. Most students perceive any dictionary as a repository of meanings of words, and if it is a dictionary, then as a repository of meanings of foreign words. At present, on the one hand, there is a noticeable need for working with texts using an e-dictionary, and, on the other hand, this problem has been little studied in the literature sources concerning teaching methods of foreign languages. M. Kruhlykova notes that the dictionary can be used not only as simple reference material but also as an independent manual for the development of all types of speech activity, for forming the communicative competence [2].

Professional and fiction texts are an important source of professionally and generally oriented information and, therefore, are a source of motivation for preparing students for international communication. Speaking about the translation of such texts, it should be noted that, like any other type of translation, it has its own characteristic features. Specialized texts are distinguished by special terminology; they may contain a large number of formulas, tables, and specific terms. The sentences are usually formulated clearly so that the reader can clearly catch the author's idea. Texts are selected according to special parameters, such as authenticity, professional orientation, interdisciplinary conditionality, reliability. At the same time, fiction texts are rich in the author's neologisms, use of unknown meanings of well-known words and word combinations.
Often students, having received a task in a foreign language, cannot fulfil it. This is usually due to the fact that they have a small stock of vocabulary. Since teaching foreign languages to students of all specialities has a practice-directed orientation, it is very important to choose the right type of the dictionary so that it reflects all the requested lexemes. As compared to printed dictionaries, their electronic analogues have more advantages, the latter can have a positive impact on the result of teaching a foreign language. There are much more possibilities using an electronic form of the dictionary, in particular, the user can quickly and accurately find out the meaning of the word he/she needs with its transcription and pronunciation. A special feature of the electronic dictionary is, first of all, the fact that it can be used to make both direct and reverse translation. This feature can productively affect the learning process.

The structure of a modern e-dictionary usually includes several dictionaries of various types. Therefore, it can be said with complete confidence that students of various specialities can easily find the requested words and phrases. Taking into account the specifics of a particular profession, it can be determined why a specialist need work with texts. Firstly, it is necessary to master the skills of reading and translation, including the correction of machine translation. Secondly, a specialist should be able to create his/her own texts in the target language - written and oral ones. It should be noted that using an electronic dictionary when working with speciality texts greatly facilitates both the work of the student and the work of the lecturer. This is primarily due to the speed and convenience that this type of dictionary provides. Although the problem under consideration has not yet been sufficiently studied, in reality using an e-dictionary when working with speciality texts brings good results in practice. When using such a dictionary, information is provided in different forms: when the user enters the desired word, textual, audio and video information appears. It can also help the lecturer to form special knowledge and skills in students. At the same time, using an e-dictionary when working with a foreign language text in a speciality can be organized at all the stages of training: when introducing new material, when revising what has already been learned, at perfection and improvement of existing skills, when exercising all the types of control.

The advantages of using e-dictionaries in foreign language classes can be, firstly, increase of the learning motivation; secondly, the autonomy of the learning process; thirdly, the occurrence of feedback (in case of inaccuracies and errors, the dictionary corrects or indicates the correct version); fourthly, insurance of the effectiveness of fulfilling assignments, compiling translations (students who regularly use the electronic version of the dictionary manually type 
sentences or texts in the interface, which naturally contributes to the speedy learning of the vocabulary).

Working with texts on a speciality using an e-dictionary can take place both individually and in a group. When working in a group, it is important to take into account the abilities of each student, as everyone possesses different knowledge of the language, so the ways of work will differ from each other. As for the individual (independent) work with an e-dictionary, it is characterized by the following: there is no time limit: the student himself/herself organizes his/her work with a dictionary in accordance with his/her needs; organizing the learning process freely; individual mode allows to select a convenient time and duration of work at performing assignment, etc.; creating comfortable conditions for students, which is an important factor when performing tasks based on texts in the speciality (there is no comparison with works of other students, a student performing the exercise can see his/ her own mistakes, tries to understand them and correct them independently) [1]. T. Karamysheva determines the following principles of work with an e-dictionary: a) the principle of informativity, which, perhaps, is the main principle, since it reflects the essence of using a dictionary at a foreign language lesson; b) the principle of necessity, which reveals the advantages of using an e-dictionary while improving the efficiency of the process of learning a foreign language; c) the principle of conditionality: it is necessary to determine accurately the conditions for using e-dictionaries, depending on the individual characteristics of students, methods of teaching foreign languages, purposes and objectives [1].

E-dictionaries, unlike traditional ones, allow their users to accelerate and mobilize the pace of learning foreign languages, to simplify searching for necessary lexical units, and to deepen and diversify learning foreign languages.

Printed dictionaries do not have the opportunity to provide each word meaning with examples of its usage. Electronic dictionaries have this feature. This helps students learn vocabulary more thoroughly, relying on examples from oral speech or fiction works. Also, a significant advantage of electronic dictionaries is using audiovisual teaching aids, i.e. illustrations, videos, audio fragments.

Conclusions. Implementing the ICTs is a priority direction of reforming of the domestic system of higher education. Performing the educational, upbringing and research functions the ICT can be used at the stage of preparing and conducting the lesson, at the stage of creating the educational-methodical provision, at the stage of the educational-upbringing process and at the stage of extracurricular activities.

Using the ICT allow creating a principally new educational sphere that gives wide opportunities to learn, affects the redistribution of roles among its participants, increasesmotivation, developsautonomy, provides individualization and differentiation of the educational process, promotes the modernization of the traditional system of education.

In particular, using the electronic dictionary at the lessons of foreign languages for students of all specialities has a beneficial effect on the learning process as a whole. Further development of the given problem will contribute to the wide dissemination of this type of work with foreign language texts in foreign language classes for students of non-linguistic specialities at the institution of higher education.

\section{REFERENCES:}

1. Карамышева Т.В. Изучение иностранных языков с помощью компьютера. В вопросах и ответах. Санкт-Петербург : Союз, 2001. 192 с.

2. Кругликова М.Ю. Использование словарей как средства повышения учебной автономии обучающихся. URL: http://festival.1september.ru/ articles/611327

3. Чернякова Л.В. Некоторые вопросы формирования экологической культуры при обучении иностранным языкам. Материалы межвузовской научно-практической консреренции. Омск, 2012. С. 77-84. 